\title{
Reading Habits and their Correlation with Reading Achievement among ESL Learners in Selected Malaysian Secondary Schools
}

\author{
Isyaku Hassan
}

Faculty of Languages and Communication

Universiti Sultan Zainal Abidin, Terengganu, Malaysia

\section{Mohd Nazri Latiff Azmi}

Faculty of Languages and Communication

Universiti Sultan Zainal Abidin, Terengganu, Malaysia

Corresponding author: mohdnazri@unisza.edu.my

\author{
Siti Normala Muhamad \\ Faculty of Social Development \\ Universiti Malaysia Terengganu, Malaysia
}

\author{
Ahmad Taufik Hidayah Abdullah \\ Faculty of Languages and Communication \\ Universiti Sultan Zainal Abidin, Terengganu, Malaysia
}

Received: 6/24/2021

Accepted: 9/15/2021

Published: 9/26/2021

\begin{abstract}
Reading is a complex process that involves cognitive, physical, intellectual, cultural, and linguistic processes. Research shows that learners who read extensively tend to accomplish a high level of academic achievement. In Malaysia, the educational goal has shifted from simply forming literate citizens to nurturing a well-educated and intellectual society. Promoting efficient reading habits can be an effective approach to realizing this goal. This study, therefore, aims to examine reading habits and ascertain their correlation with reading achievement among final-year English as a Second Language (ESL) learners in selected Malaysian secondary schools. The study utilized a cross-sectional survey in which data were gathered from a sample of 351 ESL learners using questionnaires and written tests as data-gathering instruments. The analysis was conducted by means of descriptive statistics, Pearson correlation, and simple linear regression. The findings revealed a significant relationship between ESL learners' reading habits and their reading achievement. Additionally, ESL learners' reading habits contribute significantly to their reading achievement. These findings highlight the significance of reading habits in determining ESL learners' reading achievement itself. However, this study is limited to reading habits and reading achievement among students in selected secondary schools. Thus, further research may replicate this study in the context of computer-assisted or blended learning.

Keywords: Cross-sectional survey, ESL learners, Malaysian ESL learners, reading achievement, reading habits, secondary schools

Cite as: Hassan, I., Azmi, M. N.L., Muhamad,S. N., \& Abdullah, A. T. H. (2021). Reading Habits and their Correlation with Reading Achievement among ESL Learners in Selected Malaysian Secondary

Schools. Arab World English Journal, 12 (3) 385-399.

DOI: https://dx.doi.org/10.24093/awej/vol12no3.27
\end{abstract}




\section{Introduction}

Reading, concisely, refers to "an information-processing activity, one in which an arbitrary, conventional set of symbols is used to transfer information from one mind to another" (Adams \& Brody, 1995, p. 23). Learning how to read is a process that involves several simultaneous processes, including psychological, physical, intellectual, cultural, linguistic, and educational processes (Ibrahim, 1995). From reading, a person can understand and feel other people's experiences and views. The reading process, as an integral feature of literacy (Muhamad, 2007; Pandian, 2007), is complex in its nature. Reading does not only encompass recognizing letters or words and uttering or arranging them correctly, but also, more importantly, includes the ability to understand the meanings of these arrangements (Muhamad, Azmi, \& Hassan, 2020). Today, the development of society requires that people are not expected to merely know how to read but also become proficiently literate (Abdullahi \& Rouyan, 2018; Lai, 2021). Functional literacy is acquired, as Gray (1972) pointed out, when learners have the required skills and knowledge of reading and writing which enable them "to engage effectively in all those activities in which literacy is normally assumed" (p. 24) culturally. In short, reading is a complex process that entails readers' intellectual ability, experience, and understanding of reading materials.

Rhee (2001) succinctly defined reading habits as "how often, how well, and what" individuals like to read (p. 178). Reading habits are essential in achieving positive learning outcomes. Research has shown that students who read extensively are likely to achieve good academic performance (Mwangi \& Bwire, 2020; Petrus \& Shah, 2020). Thus, reading habits are crucial, particularly in the field of education (Endris, 2018; Krashen, 2004; Makotsi, 2005). Malaysia's shift from ordinarily forming literate citizens to nurturing a well-educated and intellectual society has resulted in an adjustment in the government's educational goal (Azman, 2016). It is, therefore, suggested that promoting efficient reading habits can be an effective approach to realizing this goal (Ramasamy \& Padma, 2020). However, local studies reported mixed findings regarding students' reading habits, purposes, and types of reading materials (Azri, Fazli, \& Hafiz, 2013; Baba \& Affendi, 2020; Mansor, 2017), perhaps due to differences in study areas and populations.

Baba and Affendi (2020) reported that "students had an overall positive attitude towards academic and leisure reading" (p. 109). Nevertheless, Mansor (2017) pointed out that the government places great emphasis on examination success. This emphasis may cause students to read for examination purposes, and consequently, confine their reading to textbooks (Muhamad et al., 2020). Additionally, the government's emphasis on examination results is reinforced by regular seminars on compulsory government examinations as well as the instructors' use of an exam-oriented teaching approach to complete the syllabus in time and prepare students for examinations (Azmi, 2013). While this kind of emphasis may help students understand the importance of examinations, it may also limit their potential to acquire other equally important skills such as reading and writing.

According to the National Reading Panel (2000), reading habits are important in the development of students' reading abilities, which ultimately, helps them to acquire a holistic education. Despite the significance of reading habits in developing ESL learners' proficiency within and outside the school environment (Azmi, 2013; Balan, Katenga, \& Simon, 2019; Ihsan, 
2019; Lee \& Wong, 2017; Mwangi \& Bwire, 2020), very few studies focused on how reading habits improves ESL learners' academic performance in the Malaysian context (Lee \& Wong, 2017). Additionally, to the best of our knowledge, none of the previous local studies provides correlational evidence that reading habits improve reading achievement itself. Therefore, based on the hypothetical principle of Information Transfer theory, this research seeks to study reading habits and ascertain their correlation with reading achievement among final-year ESL learners in selected Malaysian secondary schools. The theory explains how information is transferred from reading materials to readers' minds. Based on the foregoing claims, the following research objectives were developed.

1. To examine perceived reading habits of ESL learners in the selected secondary schools in Malaysia.

2. To ascertain whether a significant correlation exists between ESL learners' reading habits and their reading achievement.

3. To determine the extent to which ESL learners' reading habits contribute to their reading achievement.

\section{Reading Habits and Academic Performance in the ESL Context}

Research shows a correlation between positive reading habits and high academic performance (Ganyaupfu, 2013; Petrus \& Shah, 2020). Similarly, ESL learners with positive reading habits tend to have higher academic performance than learners with poor reading habits (Artieda, 2017; Rimi, 2019; Vuong, Hoang, Nguyen, Ho, \& Vuong, 2021). For instance, reading habits correlate positively with writing ability at different levels (Ihsan, 2019; Khalisa, 2018; Winiharti \& Suprato, 2020). Ihsan (2019) found "a significant positive correlation between students' reading habits and their ability to write narrative texts" (p. 124). A recent study also revealed a significant association between reading habits and composition writing amongst ESL learners (Mwangi \& Bwire, 2020). Likewise, reading habits are important determinants of success in reading comprehension (Balan et al., 2019; Sulaiman \& Harpiansi, 2018; Muawanah, 2016; Najnawati, 2019; Ribqotul, 2020). Through extensive reading of academic and non-academic materials, ESL learners tend to develop critical thinking skills, vocabulary mastery, language confidence, and comprehension, which eventually leads to high academic achievements (Balan et al., 2019; Muawanah, 2016; Bendriss \& Golkowska, 2011; Ribqotul, 2020).

Additionally, Artieda (2017) used exploratory correlations to examine the impact of bilingual adult learners' first language (L1) reading ability and reading habits on the second language (L2) achievement in Spain. The learners consisted of beginners and intermediate groups and were tested based on reading comprehension and spelling. The study showed that for intermediate learners, "reading habits is the only literacy-related factor impacting L2 outcomes" (p. 168). The development of "regular reading habits of students is strongly influenced by reading culture both in families and schools" (Vuong, et al., 2021, p. 113). Parents, teachers, as well as school and socio-cultural environments can contribute significantly to developing children's reading habits (Balan et al., 2019). For instance, teachers can help students to develop positive reading habits through effective instructional strategies and quality of teaching (Balan et al., 2019; Ganyaupfu, 2013). Very few findings revealed weak correlations between reading habits and academic success in the ESL context (Ithriyah \& Nurmalia, 2021; Rahmawati, 2021). 
Moreover, extensive reading habits help "students foster skills such as thinking, valuing, adaptability and creativity" (Vuong, et al., 2021, p. 109). Reading habits were found to influence learners' knowledge acquisition, world views, as well as English speaking and writing abilities (Balan et al., 2019). Unfortunately, there is a general decline in reading habits, perhaps due to advances in new media technology, particularly social media (Jabbar \& Warraich, 2021). Obaidullah \& Rahman, 2018; Rimi, 2019). Besides, several other factors contribute to poor reading habits among ESL learners. According to Mugambi (2015), "lack of exposure to relevant reading materials, educational resources, and opportunities leads to subtle contentment alongside individual inability" to achieve academic success (p. 353). Equally, scarcity of reading materials, poverty, and traditional beliefs negatively affect the development of reading habits (Ameyaw \& Anto, 2018; Balan et al., 2019). In this regard, Mwangi and Bwire (2020) established that an "acute shortage of reading resources was a major hindrance to engagement in extensive reading" (p. 62). Concisely, "underdeveloped reading habits contribute to low academic achievement" (Mugambi, 2015, p. 353).

In essence, most previous studies revealed a positive correlation between reading habits and language proficiency. Thus, ESL learners must improve their reading habits to accomplish the desired level of language proficiency (Ribqotul, 2020). Achieving a high level of reading habits enables students to develop language confidence and expertise (Muawanah, 2016). According to Rimi (2019), reading habits "enhance retention capacity in students" at all levels (Rimi, 2019, p. 250). The studies were conducted in different countries, including Indonesia (e.g. Najnawati, 2019; Ithriyah \& Nurmalia, 2021; Winiharti \& Suprato, 2020), Kenya (e.g. Mwangi \& Bwire, 2020), Bangladesh (e.g. Rimi, 2019), and Spain (e.g. Artieda, 2017) at different levels of education. This global attention to the area of reading habits and academic performance implies that reading habits are important determinants of success among students.

In Malaysia, studies reported mixed findings concerning students' reading habits. While some findings reported positive reading habits among students (Baba \& Affendi, 2020; Schaar, Lapasau, \& Ng, 2013), others highlighted poor reading habits (Annamalai \& Muniandy, 2013; Mansor, 2017). Besides, a few findings suggested neutral habits towards reading (Fauzi, 2020). In addition, some local studies have highlighted the importance of reading habits (Azmi, 2010; Lee \& Wong, 2017), but very few studies examined the association between reading habits and ESL learners' proficiency. For instance, Lee and Wong (2017) ascertained the influence of reading habits on English language proficiency, particularly the development of vocabulary and writing skills. The overall findings showed "a trend towards a relationship between reading habits and vocabulary" (p. 167). However, none of the recent previous studies attempted to correlate reading habits with reading achievement among ESL learners in Malaysia. It was, therefore, deemed necessary to examine ESL learners' reading habits and determine the extent to which they influence reading achievement in the Malaysian context. It was envisaged that the present study would draw valid conclusions on reading habits and their correlation with reading achievement among ESL learners in selected Malaysian secondary schools.

\section{Theoretical Approach}

This study adopts Information Transfer theory to examine reading habits and their correlation with reading achievement among ESL learners in Malaysian secondary schools. This theory consists of a set of reading models that focus on how information is transferred from texts to 
readers' minds and consider reading as a method of information transfer (Gough, 1972). It best measures students' understanding of reading materials based on the amount of information conveyed. The theory, which is primarily influenced by cognitive psychology, represents the presumption that reading is a system of information transfer. In this sense, "readers extract meaning from written materials by processing the text in a linear way, allowing them to transfer meaning from the written materials to their minds" (Muhamad et al., 2020, p. 1155). The theoretical framework of this study is depicted as follows.

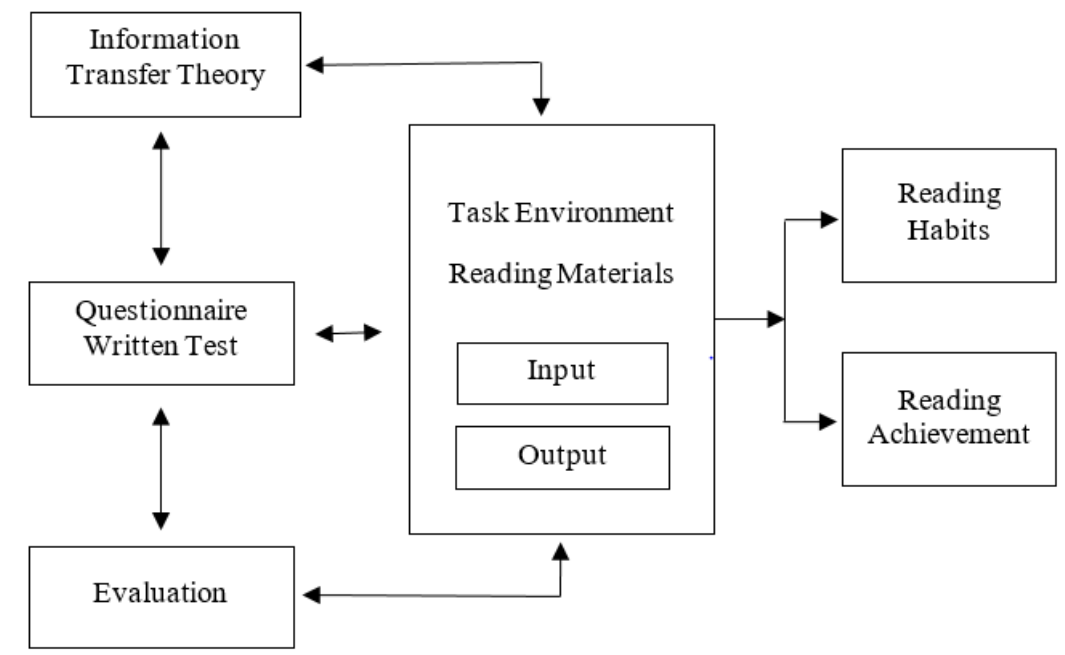

Figure 1. Theoretical Framework

Besides the extraction of meaning from texts, reading serves as a process of relating information obtained from texts with readers' knowledge (Gough, 1972). Thus, "reading is a matter of making sense of written language rather than decoding print to sound" (p. 2). Top-down strategies consist of ascertaining major thoughts, observing how new information fits the reading material generally by means of contextual knowledge, skimming, or predictions (Omale, 2015). Whereas, bottom-up strategies focus on detecting the connotation and linguistic category of specific words and sentence structure. According to Azmi (2010), successful readers use a combination of both top-down and bottom-up strategies.

Determining the role of reading habits in improving learners' ability to transfer information from texts to their minds is paramount (Smith, 1994). This is because learners with positive reading habits are expected to achieve a high level of reading ability (Bendriss \& Golkowska, 2011; Ribqotul, 2020). Good readers, then, possess the ability to transfer information from reading materials to their minds. Thus, the success of reading habits depends on the amount of information obtained by readers. When students develop positive reading habits, they are likely to transfer useful information from written materials to minds. Based on the above assumption, the following hypotheses were formulated.

$\mathrm{H}_{1}$ : A significant correlation exists between ESL learners' reading habits and their reading achievement.

$\mathrm{H}_{0}$ : A significant correlation does not exist between ESL learners' reading habits and their reading achievement.

$\mathrm{H}_{2}$ : ESL learners' reading habits contribute significantly to their reading achievement. 
Arab World English Journal (AWEJ) Volume 12. Number 3. September 2021

Reading Habits and their Correlation with Reading Achievement

Hassan, Azmi, Muhamad \& Abdullah

$\mathrm{H}_{0}$ : ESL learners' reading habits do not contribute significantly to their reading achievement.

\section{Methodology \\ Design}

In this study, a cross-sectional survey method was used to determine ESL learners' reading habits and their connection with reading achievement. A cross-sectional survey, according to Creswell (2012), represents one of the widely-used forms of survey designs. In the crosssectional survey method, data are gathered at a particular moment in time. This research design has various advantages, such as measuring the characteristics, opinions, attitudes, practices, and behaviors of a large group of individuals. It also facilitates the data collection process by providing sufficient information in a short possible time (Cohen, Manion, \& Morrison, 2007). Additionally, a cross-sectional survey allows for the generalization of outcomes to a larger population (Creswell, 2008; Neuman, 2000).

\section{Population}

A sample of 351 students was drawn from a population of 3,735 secondary school students based on Krejcie and Morgan's (1970) sampling technique. Konting (2000) also suggested that 10-20 percent of the actual population can be adequate for analysis. The sample consists of final year students from selected secondary schools in Terengganu, Malaysia. The students were selected using simple random sampling. Being final year students, they have been studying English for almost 12 years and are ready to take the Malaysian University English Test (MUET). Accordingly, this group of students can comment openly on their reading habits as they have reached a certain level of maturity.

\section{Data Collection}

This study used questionnaires and written tests as data-collection instruments. The questionnaire was adopted from two past studies (Clark \& Foster, 2005; Long et al., 1984) that analyzed reading habits and then modified to suit the purpose of this study. The questionnaire was constructed based on the Five-point Likert scale. The questionnaire contains 56 items across reading materials, motivation, place, duration, time, and reading activities. This is because, in measurable terms, reading habits are defined from various perspectives, including reading materials, reading frequency, reading time, reading duration, and reading motivation (Wagner, 2002). The reading materials consisted of newspapers, magazines, books, and online materials. The learners were asked to respond to the questionnaire within 15-20 minutes. The concept of reading habits and the research purpose were clearly explained to the respondents. On the other hand, test items were developed based on the 2019 examination paper produced by the Terengganu State Education Department (TSED), which was consistent with the reading comprehension format of MUET. The test consists of 45 questions expected to be answered within 90 minutes. Before taking the test, respondents were exposed to the KWL reading method adapted from O'Brien (2007) to guide them through the reading process. This method is proven to activate students' background knowledge, guide their reading as well as organize their thoughts to allow for greater cognition (Sholeh, Rosalina, \& Weganova, 2020; Tok, 2013).

\section{Data Analysis}

The data analysis was conducted using descriptive statistics, Pearson correlation, and linear regression analysis. The descriptive statistics, particularly mean and standard deviation, were 
used to report the respondents' reading materials, motivation, place, duration, time, and reading activities. Additionally, Pearson correlation was used to determine the correlation between the respondents' reading habits and reading achievement. Whereas, simple linear regression analysis was applied to ascertain the extent to which ESL learners' reading habits contribute to their reading achievement. Researchers have demonstrated the relevance of inferential statistics in measuring parameters of estimate and making generalizations about research populations (Hoon \& Fah, 2009; Konting, 2000; Pallant, 2001). Linear regression was considered applicable as this study deals with a large population sample (Bujang, Sa'at, \& Bakar, 2017). All calculations were made via the SPSS software (V20) at an alpha level of $\leq 0.05$.

On the other hand, the test was assessed based on the MUET standards of reading assessment. Reading ability is an important aspect of MUET that is considered obligatory for pre-university students. The test consists of six passages that focused on reading abilities such as skimming and scanning, making inferences, predicting outcomes, transferring information, drawing conclusions. The main objective of this analysis was to ascertain the correlation between the respondents' reading habits and their reading achievement, particularly in connection with MUET.

\section{Reliability and Content Validity}

To ensure reliability and validity, the research instruments were evaluated by experts to determine their relevance and applicability, and subsequently, the items were refined. According to Airasian and Gay (2003), validity is the ability of an instrument to measure what research variables. Subsequently, the questionnaire items were measured using the Cronbach Alpha formula developed by Cronbach (1951). The questionnaire was distributed to a chosen sample of 50 final year students from two secondary schools: SMK Kuala Telemong and SMK Matang. The analysis revealed a Cronbach Alpha of 0.791 regarding the students' reading habits, which suggests a high level of reliability (Wiersma, 2000). Cronbach Alpha is computed in terms of the average inter-correlation among items. This study also employed a Normal PP plot to ascertain whether the data were distributed normally according to regression standardized residual as well as regression standardized estimated values. This is because data need to be in a normal distribution to allow for parametric analysis, for example, hypothesis testing (Abu Bakar, 2007, Park, 2008). Thus, data are considered to be normally distributed once the dots lie in straight lines. The data analyzed in this study have constant variance as there was no pattern. Accordingly, linearity and homoscedasticity were presumed.

\section{Findings}

All questionnaires (351) were returned and found valid for analysis, which suggests a very high response rate. The demographic data showed that 327 , amounting to $93.2 \%$ of the respondents, were Malays, $23(6.5 \%)$ were Chinese, while only one $(0.3 \%)$ respondent belongs to other ethnic groups. Regarding the respondents' gender, 129 were males, equivalent to $36.8 \%$, whereas 222 $(63.2 \%)$ were females. This uneven distribution was because the selected schools had more female students than male students. No attempt was made to use stratified sampling as gender was not considered as a variable in this study. Additionally, $198(56.4 \%)$ respondents were from urban areas, $130(37.0 \%)$ were from suburban areas, while only $23(6.6 \%)$ were from rural areas. It is not astonishing that a large majority of respondents from urban areas participated in this study as only secondary schools in the district of Kuala Terengganu were chosen. The district 
also has a high population with multiracialism. This study, firstly, seeks to study ESL learners' perceptions of their reading habits. The ESL learners' reading habits were measured based on reading materials, motivation, place, duration, time, and reading activities. According to the Five-point Likert scale, mean values range from 0.1-5.0, the measurement of constructs ranges from 0.00 to 5.00. The ESL learners' perceived reading habits are reported in Table 1 as follows.

Table 1. ESL learners' reading habits

\begin{tabular}{|c|c|c|c|}
\hline Reading Habits & $\mathrm{N}$ & Mean & Standard Deviation \\
\hline Reading materials & 351 & 3.545 & 0.477 \\
\hline Reading motivation & 351 & 3.999 & 0.498 \\
\hline Reading place & 351 & 3.692 & 0.490 \\
\hline Dearing duration & 351 & 3.384 & 0.449 \\
\hline Reading time & 351 & 3.630 & 0.432 \\
\hline Reading activities & 351 & 3.816 & 0.443 \\
\hline Total & & 3.680 & 0.465 \\
\hline
\end{tabular}

Levels of measurement: $0.1-2.99=$ low, 3.0-3.49=moderate, 3.5-5.0=high.

Overall, the students' perceived reading habits are highly positive with a mean value of 3.68 as shown in Table 1. This outcome suggests that the selected ESL learners have a high level of reading habits. Further, reading motivation possesses the highest mean value (Mean=3.999), which signifies that the students are highly motivated toward reading activities. However, reading duration has the lowest mean value at a moderate level (Mean=3.384), suggesting that the students' reading time is insufficient to some extent. Additionally, the students are highly interested in reading English materials (Mean=3.545), particularly newspapers, magazines, books, and online materials. Likewise, the students' reading places are suitable and highly conducive (Mean=3.692. They also read English materials frequently (Mean=3.630) and participate in reading activities frequently enough (Mean=3.816). Secondly, this research seeks to ascertain whether a significant correlation exists between ESL learners' reading habits and their reading achievement. This information is depicted in Table 2 as follows.

Table 2. Learners' reading habits and reading achievement

\begin{tabular}{|c|c|c|c|}
\hline Variables & Correlation & $\begin{array}{c}\text { Reading } \\
\text { habits }\end{array}$ & $\begin{array}{c}\text { Reading } \\
\text { achievement }\end{array}$ \\
\hline \multirow{3}{*}{$\begin{array}{c}\text { Reading } \\
\text { habits }\end{array}$} & Pearson Correlation & 1 & .276 \\
\cline { 2 - 4 } & Significance (2-tailed) & & .000 \\
\cline { 2 - 4 } & $\mathrm{N}$ & 351 & 351 \\
\hline \multirow{3}{*}{$\begin{array}{c}\text { Reading } \\
\text { achievement }\end{array}$} & Pearson Correlation & .276 & 1 \\
\cline { 2 - 4 } & Significance (2-tailed) & .000 & \\
\cline { 2 - 4 } & $\mathrm{N}$ & 351 & 351 \\
\hline
\end{tabular}

$$
\mathrm{P}<0.05=0.000
$$

As shown in Table 2, the P-value for ESL learners' reading habits is lower than $0.05(\mathrm{P}=0.000)$. This outcome signifies that the coefficient for students' reading habits is significant, and hence we accept the alternative hypothesis which postulates that a significant correlation exists between ESL learners' reading habits and their reading achievement. Thus, we have evidence to reject the null hypothesis. Overall, the ESL learners' reading habits are significantly and positively 
correlated with their reading achievement, suggesting that learners who develop positive reading habits are likely to attain a high level of reading achievement. Thirdly, this research seeks to determine the extent to which ESL learners reading habits contribute to their reading achievement. This information is shown in the following tables.

Table 3. Model summary

\begin{tabular}{|l|c|c|c|c|c|}
\hline Model & Sum of Squares & $\begin{array}{c}\text { Degree } \\
\text { of } \\
\text { freedom }\end{array}$ & $\begin{array}{c}\text { Mean } \\
\text { Square }\end{array}$ & F & $\begin{array}{c}\text { P- } \\
\text { value }\end{array}$ \\
\hline Regression & 6771.162 & 2 & 3385.581 & 15.287 & .000 \\
\hline Residual & 77071.761 & 348 & 221.471 & & \\
\hline Total & 83842.923 & 350 & & & \\
\hline
\end{tabular}

Table 3 represents a summary of the model for the contribution of ESL learners' reading habits toward their reading achievement. This outcome shows that the p-value is below 0.05 $(\mathrm{P}<0.05=0.000)$. Therefore, the above model is significant enough for further analysis. As such, Table 4 depicts the extent to which ESL learners' reading habits contribute to their reading achievement.

Table 4. Contribution of reading habits to reading achievement

\begin{tabular}{|l|c|c|c|c|}
\hline Variables & $\beta$ & Std. Error & $\mathrm{t}$ & P-value \\
\hline Constant & 58.669 & 2.569 & 22.840 & .000 \\
\hline Reading Habits & 4.110 & .975 & 4.216 & .000 \\
\hline \multicolumn{4}{|c|}{$\mathrm{P}<0.05=0.000$}
\end{tabular}

Based on the information depicted in Table 3, the p-value for students' reading habits is lower than $0.05(\mathrm{P}=0.000)$. This outcome suggests that the coefficient for students' reading habits is significant, and hence we accept the alternative hypothesis which presumes that ESL learners' reading habits contribute significantly to their reading achievement. Accordingly, we have enough evidence to reject the null hypothesis. Thus, the most appropriate model is ESL learners' reading achievement $=58.669+4.110$ ESL learners' reading habits. Based on the assumptions of Information Transfer (Gough, 1972), these findings indicate that the respondents' reading habits helped them to extract meaning from English reading materials and transfer the meaning to their minds successfully.

\section{Discussion}

The findings reported in this study demonstrate that a significant correlation exists between ESL learners' reading habits and their reading achievement. Likewise, reading habits contribute significantly to ESL learners' reading achievement. These findings concur with previous investigations of the association between reading habits and reading comprehension (Balan et al., 2019; Sulaiman \& Harpiansi, 2018; Najnawati, 2019; Ribqotul, 2020). Similarly, these findings are consistent with Information Transfer theory, particularly Gough's reading model, which presumes that reading represents a method of information transfer, and in the process of information transfer, reading habits play a critical role (Gough, 1972). However, while this study established a significant correlation between ESL learners' reading habits and their reading achievement, a few previous studies reported weak correlations between ESL learners' reading 
Arab World English Journal (AWEJ) Volume 12. Number 3. September 2021

Reading Habits and their Correlation with Reading Achievement

Hassan, Azmi, Muhamad \& Abdullah

habits and language proficiency, especially vocabulary (Ithriyah \& Nurmalia, 2021) and writing abilities (Rahmawati, 2021).

Additionally, despite the importance of reading as receptive language ability and its role in developing ESL learners' language proficiency within and outside the school environment (Azmi, 2010; Lee \& Wong, 2017) and as demonstrated in this study, there has been a growing concern among researchers and educationists over students' poor reading habits in Malaysia (Annamalai \& Muniandy, 2013; Mansor, 2017). Similarly, the Malaysia Education Blueprint 2015-2025 highlights the significance of English language proficiency and communication skills (Azman 2016; Petrus and Shah, 2020). In Malaysia, literacy is a multifaceted notion because of the various languages spoken and understood by citizens of the country. As such, the educational system assumes this complex language literacy amongst the Malaysian people by offering sixyear primary education in different languages, such as English, Malay, Tamil, or Mandarin language. Bahasa Malaysia is taught as a compulsory language in all non-Malay medium institutions, while Tamil and Mandarin are taught as elective subjects. Nevertheless, English is taught at all levels of secondary schools as a compulsory second language.

Moreover, this study found that the respondents have positive reading habits to a large extent (Mean=3.680). However, this outcome does not mean that Malaysian ESL learners do not have problems concerning reading habits as highlighted in some of the previous studies (Annamalai \& Muniandy, 2013; Mansor, 2017). The findings of this study also indicated that the students' reading time appeared to be inadequate. This situation needs to be considered in developing proactive measures to enhance learners' reading habits, which could help them achieve positive learning outcomes in the ESL classroom. Teachers and parents can play a significant role in this regard (Azmi, 2010; Balan et al., 2019; Jabbar \& Warraich, 2021). This role can be facilitated by the government's effort to provide appropriate reading materials. In this regard, Muhamad et al. (2020) noted that the government can encourage students to read extensively "by providing a wider variety of good reading materials" (1159).

This study also revealed that the students are highly motivated toward reading English materials (Mean=3.999). Nevertheless, some studies conducted in the study area highlighted that one of the major problems faced by ESL teachers is the poor reading motivation among students (Azmi, 2010; Mansor, 2017). Perhaps, this problem occurs mostly when students feel that they do not have to read except for examination purposes, despite the availability of reading materials. Also, teachers often practice an exam-oriented teaching approach to complete the syllabus in time and prepare students for exams (Azmi, 2013; Muhamad et al., 2020). Another reason for the lack of motivation is the students' past examination failures. In this regard, the government has to institute programs that offer students an opportunity to rebuild their confidence and develop positive reading habits.

To sum up, this research provides evidence that reading habits contribute to reading achievement itself, and hence developing positive reading habits could help produce independent functional readers, which in turn, could contribute to the actualization of the Malaysian Government's Education Blueprint 2015-2025. The evidence of this study is that reading habits are formed through experience in the learning process and the environment. In the ESL classroom, learners are exposed to basic language components such as grammar, vocabulary, and 
literature. These early proficiencies are likely to influence students' reading habits, and eventually, help them to attain a high level of reading achievement.

\section{Conclusion}

This study is an original attempt to determine the correlation between reading habits and reading achievement among ESL learners in Terengganu, Malaysia. The current study has offered several insightful outcomes. According to the findings, a significant correlation exists between ESL learners' reading habits and their reading achievement. This correlation is a crucial aspect that needs to be considered in enhancing ESL learners' language ability because reading is a critical aspect of language proficiency. Additionally, this study revealed that ESL learners' reading habits contribute significantly to their reading achievement. If ESL learners develop positive and consistent reading habits, their reading proficiency would ultimately progress. This study provides empirical evidence concerning reading habits and their correlation with reading achievement in the ESL classroom, which could be helpful, especially to ESL teachers, on how to rectify students' reading problems.

Additionally, this study contributes to the body of reading research in the Malaysian context by highlighting the significance of reading habits in determining ESL learners' reading achievement itself. Nevertheless, this study calls for the proactive efforts of teachers, parents, and the government to enhance students' reading habits through motivations and the provision of a wide variety of quality and suitable reading materials. However, the respondents of this study are limited to final year students preparing to sit for the MUET. The study is also limited to selected ESL learners in the state of Terengganu, Malaysia. Thus, the research outcomes may not apply to other Malaysian localities. Perhaps, replicating this study in various localities would result in different and more generalizable outcomes. Also, further research may consider replicating this study in the context of computer-assisted or blended learning.

\section{About the Authors}

Dr. Isyaku Hassan is a Postdoctoral Researcher in the Faculty of Languages and Communication, Universiti Sultan Zainal Abidin (UniSZA), Malaysia. He is an active researcher with a keen interest in the areas of media linguistics, media and religion, cultural communication, interactive media, and language studies. https://orcid.org/0000-0002-8260-2894

Dr. Mohd Nazri Latiff Azmi is an Associate Professor of English Language in the Faculty of Languages and Communication, Universiti Sultan Zainal Abidin (UniSZA), Malaysia. His areas of research interest include literacy and comparative literature, language studies, and applied linguistics. https://orcid.org/0000-0002-4712-5332

Siti Normala Muhamad is a $\mathrm{PhD}$ candidate Faculty of Social Development, Universiti Malaysia Terengganu (UMT), Malaysia. She researches how reading activities in the context of English as a Second Language (ESL), particularly how reading habits and interests relate with ESL learners' reading performance.

Dr. Ahmad Taufik Hidayah Abdullah is a Senior Lecturer in the Faculty of Languages and Communication, Universiti Sultan Zainal Abidin (UniSZA), Malaysia. His areas of research 
Arab World English Journal (AWEJ) Volume 12. Number 3. September 2021

Reading Habits and their Correlation with Reading Achievement

Hassan, Azmi, Muhamad \& Abdullah

interest include public speaking, second language acquisition, reading strategies, and error analysis.

\section{References}

Abdullahi, A., \& Rouyan, N. B. M. (2018). The use of web 2.0 technologies to determine receptive skills among Malay learners of the Arabic language. International Journal of Asian Social Science, 8(9), 651-659. doi: 10.18488/journal.1.2018.89.651.659

Abu Bakar, B. (2007). Principles of data analysis in education. Kuala Lumpur: Utusan Publication.

Adams, W. R., \& Brody, J. (1995). Reading beyond words. Texas: Harcourt Brace College Publishers.

Airasian, P., \& Gay, L. R. (2003). Educational Research: Competencies for Analysis and Applications. New Jersey: Pearson Education.

Ameyaw, S. K., \& Anto, S. K. (2018). Read or perish: Reading habits among students and its effect on academic performance: A case study of Eastbank Senior High SchoolAccra. Library Philosophy and Practice, 1(2), 1-23.

Annamalai, S., \& Muniandy, B. (2013). Reading habit and attitude among Malaysian polytechnic students. International Online Journal of Educational Sciences, 5(1), 32-41.

Artieda, G. (2017). The role of L1 literacy and reading habits on the L2 achievement of adult learners of English as a Foreign Language. System, 66(1), 168-176.doi:

10.1016/j.system.2017.03.020

Azman, H. (2016). Implementation and challenges of English language education reform in Malaysian primary schools. 3L: Language, Linguistics, Literature, 22(3), 65-78.

Azmi, M. N. L. (2010). English language reading culture among primary school students in Terengganu (Unpublished Doctoral dissertation). International Islamic University, Malaysia.

Azmi, M. N. L. (2013). National Language Policy and its impacts on second language reading culture. Journal of International Education and Leadership, 3(1), 1-11.

Azri, A. M., Fazli, F. B. M., \& Hafiz, W. M. (2013, August 25-27). Understanding of reading habits among students in royal military college, Malaysia. Paper presented at the National Seminar of Malaysian Librarians, Melaka, Malaysia.

Baba, J., \& Affendi, F. R. (2020). Reading habit and students' attitudes towards reading: A Study of students in the Faculty of Education UiTM Puncak Alam. Asian Journal of University Education, 16(1), 109-122.

Balan, S., Katenga, J. E., \& Simon, A. (2019, June 26-28). Reading habits and their influence on academic achievement among students at Asia Pacific International University. Paper presented at the International Scholars Conference, Kedah, Malaysia.

Bendriss, R., \& Golkowska, K. (2011). Early reading habits and their impact on the reading literacy of Qatari undergraduate students. Arab World English Journal, 2(4), 37-57.

Bujang, M. A., Sa'at, N., \& Bakar, T. M. I. T. A. (2017). Determination of minimum sample size requirement for multiple linear regression and analysis of covariance-based on experimental and non-experimental studies. Epidemiology, Biostatistics, and Public Health, 14(3), 1-9.

Clark, C., \& Foster, A. (2005). Children's and young people's reading habits and preferences:

The who, what, why, where and when. Retrieved from:

https://files.eric.ed.gov/fulltext/ED541603.pdf 
Arab World English Journal (AWEJ) Volume 12. Number 3. September 2021

Reading Habits and their Correlation with Reading Achievement

Hassan, Azmi, Muhamad \& Abdullah

Cohen, L., Manion, L., \& Morrison, K. (2007). Research methods in education. New York: Routledge.

Creswell, J.W. (2008). Educational Research: Planning, Conducting and Evaluating Quantitative and Qualitative Research ( $3^{\text {rd }}$ ed). London: Pearson Education.

Creswell, J.W. (2012). Educational Research: Planning, Conducting and Evaluating Quantitative and Qualitative Research (4 ${ }^{\text {th }}$ ed). London: Pearson Education.

Cronbach, L. J. (1951). Coefficient alpha and the internal structure of tests. Psychometrika, 16(3), 297-334.doi: 10.1007\%252fbf02310555

Endris, A. A. (2018). Effects of extensive reading on EFL learners' reading comprehension and attitudes. International Journal of Research in English Education, 3(4), 1-11.doi:1 $0.29252 /$ ijree.3.4.1

Fauzi, N. F. M. (2020). Habits and attitude in English reading of SMK Raja Muda Musa students (Unpublished Master's thesis). International Islamic University Malaysia, Kuala Lumpur, Malaysia.

Ganyaupfu, E. M. (2013). Factors influencing academic achievement in quantitative courses among Business students of Private Higher Education Institutions. Journal of Education and Practice, 4(15), 57-65.

Gough, P. B. (1972). One second of reading. In J.F. Kavanagh \& I.G. Mattingly (Eds.). Language by Ear and Eye: The Relationships between Speech and Reading. Cambridge: Cambridge: MIT Press.

Gray, William S. (ed). (1972). Promoting growth toward maturity in interpreting what is read. Chicago: University of Chicago Press.

Hoon, K. C., \& Fah, L. Y. (2009). Introduction to statistical analysis in social science research. Selangor. Venton Publishing.

Ibrahim, M. N. (1995). A survey on the problems faced by ESL teachers in teaching listening and speaking skills to students of religious schools in Besut, Terengganu (Unpublished Master's thesis). Universiti Putra Malaysia, Selangor, Malaysia.

Ihsan, M. T. (2021). The correlation between students' reading habit and their writing ability of narrative text. Indonesian Journal of Integrated English Language Teaching, 5(2), 124130.

Ithriyah, S., \& Nurmalia, N. (2021). Relationship between students' reading habit and their vocabulary knowledge. Ethical Lingua: Journal of Language Teaching and Literature, 8(1), 144-149.

Jabbar, A., \& Warraich, N. F. (2021). Factors related to children, parents and school teachers influencing children reading habits: A review of literature. Ilkogretim Online, 20(5), 54345444.

Khalisa, N. (2018). The correlation between students' reading habit and their writing ability (Unpublished Master's thesis). Ar-Raniry State Islamic University, Aceh, Indonesia.

Konting, M. M. (2000). Principles of teacher education. Kuala Lumpur: DBP Press.

Krashen, S. D. (2004). The power of reading: Insights from the research. Westport., CT: Greenwood Publishing.

Krejcie, R.V, \& Morgan, D. W. (1970). Determining sample size for research activities. Educational and Psychological Measurement, 30(3):607-610. doi:

10.1177/001316447003000308 
Arab World English Journal (AWEJ) Volume 12. Number 3. September 2021

Lai, H. K. (2021). The effectiveness of teaching reading skills using communicative approach in Malaysian secondary homeschooling ESL classroom. International Journal of Linguistics, Literature, and Translation, 4(1), 131-158.

Lee, J. Y. V., \& Wong, A. S. C. (2017). The relationship between leisure reading habits, vocabulary, and writing of English Language Learners (ELLs). Language Education in Asia 8()2), 157-175.doi: 10.5746/LEiA/17/V8/I2/A03

Long, A. (1984). A survey on the reading habits and interests of Malaysian people. Kuala Lumpur: DBP Press.

Mansor, N. O. N. (2017). Exploring perceptions on ESL students' reading habits. Journal of Business and Social Development, 5(2), 19-24.

Makotsi, R. L. (2005). Sharing resources: How library networks can help reach education goals. London: Book Aid International.

Muawanah, S. (2016). The relationship between students' reading habit and their reading comprehension (A correlational study at Second Grade students of SMA Dua Mei Ciputat) (Unpublished Master's thesis). Sharif Hidayatullah Islamic University, Jakarta, Indonesia.

Mugambi, F. N. (2015). Exploring reading habits and academic success in rural Kenya. IFLA Journal, 41(4), 353-363.doi: 10.1177/0340035215610303

Muhamad, S. N. (2007). A Study of reading habits and interests among secondary school students in SMK Kuala Telemong, Hulu Terengganu, Terengganu (Unpublished Master's thesis). Universiti Teknologi Mara, Selangor, Malaysia.

Muhamad, S. N., Latiff Azmi, M. N., \& Hassan, I. (2020). Reading interest and its relationship with reading performance: A study of English as Second Language learners in Malaysia. Humanities \& Social Sciences Reviews, 7(6), 154-1161. doi:10.18510/hssr.2019.76165

Mwangi, F. G., \& Bwire, A. M. (2020). Role of extensive reading habits in students' acquisition of composition writing skills in English in Kenya. Journal of Education and Practice, $11(30), 62-68$.

Najnawati, N. (2019). The correlation between students' reading habit and students' reading comprehension at the Second Grade of MTs Negeri Parepare (Unpublished Master's thesis). Sharif Hidayatullah Islamic University, Jakarta, Indonesia.

National Reading Panel. (2000). Teaching children to read: An evidence-based assessment of the scientific research literature on reading and its implications for reading instruction. Retrieved from: https://eric.ed.gov/?id=ED444126

Neuman, W.L. (2000). Social research methods: Qualitative and quantitative approaches. Needham Height, MA: Allyn\& Bacon.

O'Brien, K. (2007). The effects of pre-reading strategies on the comprehension of culturally unfamiliar texts for adolescent English language learners (Unpublished Master's thesis). Hamline University, Minnesota, United States.

Obaidullah, M., \& Rahman (2018). The impact of the internet and social media on the habit of reading books: A case study in the Southern Region of Bangladesh. Studies in English Language and Education, 3(1), 25-39

Omale, H. (2015). Models and the process of reading. Awka Journal of Linguistics and Languages, 9(1), 45-56.

Pallant, J. (2001). SPSS survival manual: A step-by-step guide to data analysis using SPSS for windows. New York: Open University Press.

Park, H. M. (2008). Univariate analysis and normality test using SAS, Stata, and SPSS. Retrieved from: http://www.indiana.edu/ statmath/stat/all/normality/normality.pdf. 
Petrus, S. L., \& Shah, P. M. (2020). Relationship between reading anxiety, reading strategies, and language competence of rural ESL secondary learners. Creative Education, 11(2), 126-142.doi: 10.4236/ce.2020.112010

Rahmawati, S. (2021). Examining students' reading habits and gender differences behind Students' academic writing achievement. IDEAS: Journal on English Language Teaching and Learning, Linguistics, \& Literature, 9(1), 109-117.doi: 10.24256/ideas.v9i1.1837

Ramasamy, K., \& Padma, P. (2020). Does gender influence the reading habits, preferences, and attitudes of school students? A Case Study. Library Philosophy and Practice, 1(1), 1-64.

Rhee, A. M. S. O. (2001). Adult reading habits and patterns. Reading Psychology, 22(3), $175-$ 203.doi: 10.1080/027027101753170610

Ribqotul, A. (2020). A correlational study between reading habit and vocabulary mastery with reading comprehension (A correlation study at the Second Grade of MTS NU 1 Kramat Tegal in the academic year 2019/2020) (Unpublished Master's thesis). Universitas Widya Dharma Klaten, Java, Indonesia.

Rimi, R. N. (2019). Online reading habits of university students in Bangladesh and its effects in ESL classroom. International Journal of Education, 4(30), 251-264.

Schaar, T., Lapasau, M., \& Ng, S. F. (2013). Reading habits of Malaysian students beyond classrooms. Studies on Foreign Languages and Cultures, 2(1), 114-138.

Sholeh, A., Rosalina, N. E., \& Weganova, R. (2020). The implementation of KWL (Know, Want to Know, and Learned) to improve students' reading comprehension. Indonesian Journal of English Education, 7(1), 22-31.doi:10.15408/ijee.v7i1.15541

Smith, F. (1994). Understanding reading. Hillsdale, NJ: Lawrence Erlbaum.

Sulaiman, M., \& Harpiansi, H. (2018). The correlation between reading habit and students' reading comprehension achievements. Alsuna: Journal of Arabic and English Language, 1(2), 78-86.doi: 10.31538/alsuna.v1i2.87

Tok, Ş. (2013). Effects of the Know-Want-Learn strategy on students' mathematics achievement, anxiety, and metacognitive skills. Metacognition and Learning, 8(2), 193-212.doi: 10.1007/s11409-013-9101-z

Vuong, H. M., Hoang, P. H., Nguyen, M. H., Ho, M. T., \& Vuong, Q. H. (2021). Reading habits, socioeconomic conditions, occupational aspiration and academic achievement in Vietnamese Junior High School students. In Q. Vuong, L. A. Vinh, \& T. Trung (eds.), Academic Contributions to the UNESCO 2019 Forum on Education for Sustainable Development and Global Citizenship (pp. 109-137). Switzerland: MDPI.

Wagner, S. (2002). The reading habits of teams. Journal of Reading Today, 46(3-4), 122-123. Wiersma, W. (2000). Research methods in education ( $7^{\text {th }}$ ed.). Ohio: University of Toledo. Winiharti, M., \& Suprato, D. (2020). Is college students' reading habit truly related to their writing ability? Humaniora, 11(2), 103-112.doi: 10.21512/humaniora.v11i2.6427 